Modes of Organizing Biomedical Innovation in the UK and US and the Role of Integrative and Relational Capabilities

Jacky Swan a, Anna Goussevskaia ${ }^{b}$, Sue Newell', Maxine Robertson ${ }^{\text {d }}$, Mike Bresnen $^{\mathrm{e}}$ and Ademola Obembe ${ }^{\mathrm{a}}$

\footnotetext{
${ }^{a}$ Warwick Business School, University of Warwick, Coventry, CV4 7AL, UK

${ }^{\mathrm{b}}$ Warwick Business School, UK / Fundação Dom Cabral, Brazil

${ }^{\mathrm{c}}$ Bentley College, 175 Forest Street, Waltham, MA 02452 U.S.A Boston, USA

${ }^{\mathrm{d}}$ Coventry University, Priory Street, Coventry, CV1 5FB, UK

${ }^{\mathrm{e}}$ University of Leicester Management Centre, University Road, Leicester, LE1 7RH, UK
}

Contact: jacky.swan@wbs.ac.uk (024 7652 4271) 


\title{
Modes of Organizing Biomedical Innovation in the UK and US and the Role of Integrative and Relational Capabilities
}

\begin{abstract}
Biomedical innovation typically involves intense collaboration across diverse disciplines, occupations and organizations. Given this, a nation's integrative capabilities (the ability to move between basic science and clinical development) and relational capabilities (the ability to collaborate with diverse organizations) have been identified as crucial for encouraging innovation. However, the impact of such capabilities on innovation has been considered, to date, mainly in macro, structural terms - explaining US national competitive advantage, for example. This paper draws, instead, from a qualitative analysis of biomedical innovation in the UK and US to identify mechanisms influencing innovation at the project level through which macro level capabilities may be having effects. From this we develop a propositional framework that helps to explain the likely impact of such capabilities for characteristically different kinds of innovation projects at the micro level.
\end{abstract}

\section{Key words}

Integrative capabilities, relational capabilities, innovation, organization, biomedical 


\section{Introduction}

Biomedical innovation has been defined in various ways but here we see it as a process involving the creation and application of scientific and technological knowledge to improve the delivery of human healthcare and the treatment of disease. This definition is broad enough to include new drugs, diagnostics, and drug delivery regimes for human use, but excludes purely animal, agricultural and natural resource applications of biotechnology (Rasmussen, 2005). In the biomedical domain, the potential for breakthroughs in science and technology to radically change (and hopefully improve) medical treatments and diagnostic techniques, is high. However, exploitation of scientific breakthroughs for biomedical innovation is problematic, as witnessed by the high cost, duration and failure rates in product development (CMR International, 2006).

Even where scientific knowledge is validated, many promising discoveries fail to reach the clinic, with a significant number of failures occurring in early development phases of the innovation process (Hilton et al, 2002; Dopson, 2005). This is, in part, because biomedical innovations - especially more radical innovations - often cut across established professional, occupational and organizational boundaries, and threaten to disrupt existing medical practice (Christensen, 2000). This suggests that the ability to combine and integrate knowledge (scientific, technological, commercial, clinical, regulatory) across a distributed array of professional groups, commercial organizations, public research organizations (PROs), and health organizations would be central to biomedical innovation (Gibbons et al., 1994; Coombs et al, 2003). Biomedical innovation processes have thus been described as typically non-linear or 'interactive', comprising complex, uncertain, high risk, and iterative cycles of knowledge integration and networking across these diverse groups (Powell et al, 1996; Dodgson et al, 2004). 
As Powell et al., (1996), note: “when the knowledge base of an industry is both complex and expanding, and sources of expertise are widely dispersed, the locus of innovation will be found in networks of learning, rather than individual firms”.

The structural features of networks (e.g. their density, scope, strength of ties) linking PROs to commercial firms have been subject to a good deal of analysis (Powell et al., 1996; Owen-Smith et al, 2002). This work has shown how systematic variation in the composition of networks across nations, and within regions, influences the ability to integrate scientific, clinical and commercial expertise (Owen-Smith et al, 2002; OwenSmith and Powell, 2004). Of particular importance for biomedical innovation are linkages between scientific research and commercial and clinical development. OwenSmith et al (2002) identify two macro-level capabilities that influence these linkages: 'integrative' and 'relational' capabilities. These refer, respectively, to the ability of scientists to move back and forth between basic science and clinical development; and to the ability of organizations within an innovation system to collaborate with other, diverse organizations. In keeping with 'national innovation systems' approaches, their work suggests that these capabilities stem from macro-level institutional differences in the structure and operation of networks and, thus, differ across nations (Carlsson 2002; Nelson 1993). In particular, Owen-Smith et al (2002), through an analysis of 'upstream' R\&D linkages, have demonstrated that these capabilities are better developed in the US institutional context than in Europe (including the UK). This, they suggest, accounts (at least in part) for the US national advantage in biomedical innovation.

As yet, however, relatively little research has focused on identifying and explaining the ways in which such macro capabilities relate to the process of innovation itself. Thus, 
whilst there is now evidence linking macro data on networks to quantitative indicators of innovation (e.g. the development of patents or the diffusion of innovations), there is also scope for qualitative research to complement this by investigating the processes through which macro-level capabilities play out in the experiences of actual innovation projects, as perceived by the various stakeholders involved (Owen-Smith, 2003; Rogers, 1995). For example, how might the ability of scientists to move back and forth between basic science and clinical development (i.e. integrative capabilities) facilitate an innovation process in a particular project setting? In answering this question we seek to identify the specific mechanisms through which macro capabilities are likely to have effects on innovation projects. Within national institutional contexts, there are also clearly wide variations in the ways that innovation projects linking public and private science are actually organized (e.g. as university start ups, as development projects in biotechnology firms, as R\&D projects in global pharmaceutical firms). Our research also seeks to identify different types of organizational arrangement for biomedical innovation and to explore how these variations in the organization of innovation might mediate the impact of a nation's integrative and relational capabilities at project level.

Reflecting the absence of prior work, this study is exploratory, inductive and broadlybased. This means that, whilst we can identify mechanisms at project level that link to macro capabilities and play an important role (in our cases) in shaping innovation processes, and have explored these across contexts (UK, US and different types of project), our data does not allow us to conduct direct comparative analysis along dimensions defined 'a priori'. That said, our findings are suggestive of comparative differences and new theoretical propositions which future, more deductively oriented work could follow-up. 
Our argument is structured as follows. We begin by outlining previous literature on the role of integrative and relational capabilities across contexts and attempt to link this to innovation processes. We focus in our study on the UK and US since, whilst these both have well developed biomedical industries, previous work has found that they are characteristically different in terms of integrative and relational capabilities making (to put it crudely) the US context more supportive of biomedical innovation (Owen-Smith and Powell, 2003). However, it should be noted that our study is focused on innovation processes - it is not attempting directly to confirm or refute these earlier, macro findings.

We turn next to the nature of biomedical innovation processes and suggest that, as these nearly always entail interactions and interdependencies across specialist knowledge domains and organizations, a more differentiated framework is needed to understand how such processes are organized. Thus the first phase of our research study involved an interview-based survey of key stakeholders in the US and UK, combined with review of existing literature, in order to develop a framework to capture characteristically different modes of organizing biomedical innovation projects. This framework is summarised and used as a basis for case selection. We then focus our analysis on detailed, longitudinal case studies in order to identify those mechanisms at project level that appeared to play an important role in shaping innovation processes, and which could be related to macro-level capabilities. In keeping with our research aims, the rationale for selecting characteristically different kinds of project was not direct case comparison but to capture variation across contexts (Alvesson and Skoldberg, 2000). Thus, if a particular mechanism could be identified as relevant across contexts, then we 
could be more confident of its explanatory value as a basis for further research. In the concluding section, we attempt to relate the ways in which integrative and relational capabilities play out in particular kinds of project through the development of a new propositional framework to guide future research.

\section{Integrative and Relational Capabilities Across Contexts}

The impact on innovation of national institutional contexts has clearly been the subject of a significant amount of research (Whitley, 2003). We have chosen in our study to focus on the UK and US because their national systems of innovation have been found in previous work to be largely supportive of biotechnology innovation (Casper and Kettler, 2001; Whitley, 2000, Casper, 2000) - both have world class research facilities and science bases and internationally recognized pharmaceutical firms and both support entrepreneurial activity and have active local markets in the supply of technology, scientists and know-how. Recognizing these similarities, there are also crucial differences that make them interesting points of contrast. Clark $(1987$; 2003), for example, suggests that the UK and US have nationally distinctive patterns of innovation and distinctive cultural repertoires or 'styles of thinking' amongst managers, and the impact of professional and educational institutions on the legitimation of knowledge has been found to vary across these contexts (Clark, 2000; Aldrich, 2000).

In the context of biomedical innovation, Owen-Smith et al's (2002) delineation of integrative and relational capabilities - capabilities that link scientific research to clinical and commercial development - is particularly helpful in understanding the institutional factors that may promote innovation. Integrative capabilities facilitate the translation of basic research into commercial applications through the movement of 
scientists and their enhanced labour market mobility (cf. Henderson, 1994). In contrast, relational capabilities facilitate innovation by, for example, supporting collaborative product development projects between PROs, biotechnology firms, and pharmaceutical firms. The key elements in forming these capabilities are linkages across life science networks that structure national innovation systems. These linkages have been found to be influenced by the macro institutional context, including political (e.g. policy initiatives, regulation), social (e.g. relations between scientists and technologists, the mobility of the scientific labour force) and cultural (e.g. values regarding academic participation in commercial activities) factors (Owen-Smith et al, 2002).

The impact of integrative and relational capabilities on biomedical innovation has been demonstrated through macro-level data comparing the US and Europe (including the UK). Thus Owen-Smith et al (2002) find that the organization of upstream (early stage) $\mathrm{R} \& \mathrm{D}$ in the US is qualitatively different to Europe, embracing more diverse constituents and knowledge sources, closer linkages between basic science and applied science, and closer links between public and private organizations - in the form of dense regionallyclustered networks (mainly in Boston, California and New York) among hospitals, dedicated biotechnology firms, large pharmaceutical firms, universities and research institutes. Like others, they argue that the US context has a stronger history of industryuniversity collaboration in R\&D (Rosenberg and Nelson, 1994) with more, and more diverse, interfaces between public and private organizations. This reflects national differences in educational systems, career development and labor markets (for example, greater, and more diverse, funding of universities in the US) and the greater movement of academics back and forth between PROs, firms and research hospitals (Whitley, 2003). 
With regard to integrative capabilities, these have been linked to national institutional differences in educational systems, career development and labor market mobility (Whitley, 2003). For example, in the US context, scientists are more able to move back and forth between the public and private sector without detriment to their scientific careers, as compared to those working in the UK (Owen-Smith et al., 2002; Powell et al., 1996; Mallon et al, 2005). This chimes with work which suggests that the US has a stronger 'knowledge plus’ orientation, where joint goals of understanding and use and of basic science and commercialization are more strongly established (Stokes, 1997). This is seen to generate a US advantage in terms of the ability to develop and exploit scientific knowledge for clinical development (Owen-Smith et al, 2002). In contrast, the relationship between PROs and private firms in the UK is more distant: PROs tend to be more specialized and there is a greater distinction between basic research and development. These findings concur with Clark (1987) who observes greater 'conflict with capital' in the UK educational system, with a more pragmatic orientation towards applied, or 'how to', knowledge in the US, as opposed to the stronger value placed on knowledge and understanding for its own sake in the UK. This, he argues generates a polarization in the UK between "academic thinking, which is often regarded as unnecessary and impossible to digest and the rule of thumb empiricism which seems to have a firm grip in many sectors” (p.223). Whilst Nowotny et al (2001) note the increased blurring of boundaries between knowledge traditionally produced in university, government and private sector research organizations, this is also deeply politicized so that “the university appears simultaneously as capturing, but also captured” (p. 79). 
With regard to relational capabilities, there is ample evidence that individual firms, even large pharmaceuticals, do not possess all of the resources necessary to successfully develop new therapeutics (Powell et al, 1996). Individuals and firms, therefore, need to collaborate formally and informally to acquire the necessary resources. In the biotechnology sector, 'open' channels have been found to be particularly helpful in facilitating opportunities for knowledge creation through the enhanced likelihood of 'spillover effects': that is, knowledge is more likely to 'leak' though more open channels (Owen-Smith and Powell, 2004; Murray, 2002; Kreiner and Schultz, 1993). Similarly, Salman \& Saives (2005) show that, as well as being influenced by direct relationships between organizations, innovation outcomes are attributable to informal, unpredictable relationships generated through indirect ties, which create access to expertise beyond formal alliance partnerships. Other literature has emphasized the importance of trust-based, informal networks for R\&D (e.g., Leibeskind et al., 1996; Kreiner and Schultz, 1993). The US biomedical sector has also been found to have better established relational capabilities than in Europe reflected, for example, in the scope and density of networks - at least in certain regions.

This prior research is indicative of the ways in which integrative and relational capabilities might influence innovation processes in broad terms. For example, it suggests that one important mechanism via which integrative capabilities could influence innovation at project level is through the career identities and values of individual scientists involved in project work, in particular the extent to which they see goals of science and commerce as mutually acceptable. Similarly, relational capabilities at the macro level (as indicated in prior research by the density and scope of network ties within regions and nations) would appear to be related, at project level, to the ability 
of the organizations involved in innovation processes to acquire and create relevant expertise, with informal networks being especially important in this respect. However, further research is needed to explore these mechanisms in detail. The value of understanding relationships across different levels of analysis has also been observed by Gittell and Weiss (2004) who note that, “frameworks for analyzing organizational phenomena must be responsive to the dynamic and complex characteristics and interrelationships between multiple levels of analysis that 'real life' situations reflect”. As already seen, an important aspect of these dynamics in the case of biomedical innovation concerns the ways in which networked relations and the combination of specialist forms of knowledge and expertise are actually coordinated amongst the different parties involved in innovation projects. In the analysis below, then, we begin by identifying characteristically different modes of organizing biomedical innovation projects (focusing on network relations and knowledge flows, before looking across different kinds of project in the UK and US to draw out those mechanisms that appear to be important in relating macro capabilities to actual innovation processes.

\section{Methodology}

The findings below are drawn from a 3-year exploratory study of innovation in the UK and US biomedical sectors aimed at identifying the factors facilitating and impeding innovation projects across contexts. The UK and US contexts were selected in order to achieve broadly defined variation (Alvesson \& Skoldberg, 2000) as earlier work had suggested that macro level relational and integrative capabilities were different across these two contexts (Owen-Smith et al, 2002). 
The first phase was an interview-based survey with a range of individuals representing key stakeholder groups who had significant experience of working in early-stage biomedical innovation projects that could be described as involving 'systemic production networks' (Alter and Hage, 1993). Interviewees were initially identified via members of our project's expert UK and US Scientific Advisory Boards (SAB). Members of the SAB were all experienced in managing biomedical innovation, and included serial entrepreneurs of biotech companies, venture capitalists, academic scientists, and policy specialists. From these initial contacts, additional interviewees were identified using a 'snowballing' technique. This kind of non-probability convenience sampling is appropriate when the research is exploratory and population parameters are unknown (Saunders et al, 2000).

We conducted 97 interviews (44 UK; 53 US). In addition, 22 meetings were held to discuss further participation as case studies for phase two (17 UK; 5 US). Recognizing that there are regional variations, field work focused on the Boston area in the US, which has a concentration of biomedical-related organizations (including Harvard, MIT and Mass General, for example). In the UK, we concentrated on the Oxford Cambridge - London triangle, which is also recognized for its high level of activity and reputation for innovation in the biomedical area. The primary aim of these first phase interviews was to gather rich, and broadly representative, descriptions of experiences of innovation in the biomedical field from those directly involved. In particular, we wanted to establish the different ways biomedical innovation projects were organized. Whilst the dimensions we identified (organizational coupling and knowledge boundaries, see below) do resonate with earlier work (Alter \& Hage, 1993), this earlier work had not specifically considered biomedical projects, or the relationship between knowledge 
flows and networks in systemic production networks which relational and integrative capabilities directly relate to.

The second phase comprised longitudinal case studies of innovation projects (six in the US and four in the UK), offering exemplars of different ways of organizing biomedical innovation. The particular focus was on early development (the move from discovery to the early stages of commercialization) as the first phase identified this as a critical point at which upstream scientific expertise needed to interact with other forms of expertise (clinical, commercial, regulatory) and where integrative and relational capabilities would be expected to have a significant impact (Owen-Smith et al, 2002). A key criteria for case selection was, not only that the case appeared to offer a good example of a particular mode of organizing as identified by phase 1 , but also that good access to key stakeholders was offered, allowing us to conduct detailed longitudinal research including, for example, allowing investigators non-participatory observation of strategy and project meetings and access to meeting notes.

Our approach was rooted in social constructivism (Kuckla, 2000) and therefore a subjective rather than an objective epistemology was assumed (Denzin \& Lincoln, 1998). Hence, we did not aim to compare cases along fixed dimensions such as ‘success' of projects, as we accepted that what counted as ‘success' was socially constructed by those involved. For example, in some projects, the acquisition of funding constituted 'success' when this facilitated future development work and enabled progress to be made on projects. In others, clinical trial results which secured gateway FDA approval served as an important proxy for success by those involved. The length of time available to study these projects (@30 months) was adequate to trace what 
progress (if any) had been made on projects and what factors may have facilitated or hindered projects. Thus on each case visit (held approximately 6 monthly) project team members were asked to review whether progress had matched their expectations in the prior period and also to indicate their expectations for the forthcoming period. However, the time available was not sufficient to assess 'success' in definitive terms as the entire development process would take around 8 years on average (CMR International, 2004). This collective case study approach was aimed at facilitating interpretation and developing qualitative insights into the early-stage development process (Alvesson \& Skoldberg, 2000), by comparing the similarities and differences provided by multiple settings - in this case - projects (Tsoukas, 1989).

Whilst access was negotiated via focal organizations and/or individuals, the unit of analysis was the innovation process, as manifest in particular projects over the period of the research, not a specific firm, so interviewees spanned the different organizations involved. The cases were selected on the basis of, first, the choice of research topics and questions being posed (Stake, 1995) and, second, the possibility of capturing both historic and 'live' processes to inform the longitudinal analysis (Pettigrew, 1990). Thus in all cases, activity relating to the innovation process had been on-going for at least 2 years and was projected to continue during the research period. This permitted the collection of data providing current, as well as retrospective, views of the innovation process. This case research was interview based, with a minimum of 4 fieldwork visits per case over the 30 month period. On average, 14 interviews were conducted per case. Interviews were complemented with access to extensive documentary data (including companies’ reports, inter-partner correspondence, contracts, and meeting minutes) and observational data (including non-participant observation of project team and advisory 
board meetings). The interviews in both phases were recorded and transcribed. Detailed notes were taken and later written up as a record of any meetings attended.

The first phase data were coded and analysed using NVivo software and the 'memoing' technique (Glaser, 1978; Miles \& Huberman, 1994). Interviewees were asked to recount stories of their own experiences of biomedical innovation projects and to talk about the factors and critical events that had influenced these projects. In the analysis we focused on identifying the institutional level factors that interviewees discussed as either facilitating or impeding the innovation process described. This included, for example, access to finance, availability of expertise and access to technology. We used this analysis to consider how institutional-level relational and integrative capabilities were playing out in different innovation projects.

In phase two, recognizing the complexity of the cases, the research for each case was jointly conducted by at least two investigators in order to co-develop interpretations in real time throughout the research period. Data were managed, coded and recoded, using NVivo, the initial coding structure having been developed from phase 1. On completion of fieldwork, detailed case descriptions were produced by the investigators on each case (on average 10,000 words) containing primary data (quotes from interviews, inserts from documents etc.), and structured according to particular themes. All case descriptions were then content analyzed by the whole team in order to identify the processes and project dynamics that facilitated or impeded project progress (however defined by project participants), relating each to either the ability of scientists to move back and forth between basic science and clinical development (i.e., linked to macrolevel integrative capabilities), or to the ability of organizations within an innovation 
system to collaborate with other, diverse organizations (i.e., linked to macro-level relational capabilities). We refer to these processes and dynamics for convenience as 'mechanisms' and the analysis below explains why and how we see these mechanisms as related to macro capabilities.

Initially 12 mechanisms were identified, which related to integrative capabilities and 17 mechanisms, which related to relational capabilities. Further inductive analysis of these 29 mechanisms by each team member and then by the whole team led to a clustering of these into 8 primary mechanisms identified from the 10 cases. The major criteria by which interpretive research is assessed - trustworthiness, credibility, confirmability and transferability - were therefore addressed by independent verification across the 10 case studies and the 6 researchers on the project (Denzin \& Lincoln, 1998). In addition, over the duration of the research, 5 SAB meetings were also held. At each of these meetings major findings to-date were discussed, including, at the final meeting, a detailed discussion to test our analysis of how the mechanisms we identified linked to macro capabilities (most SAB members having had experience of both US and UK contexts). We explicitly sought from our advisory board members, feedback as to how far the categories, models and frameworks that we were developing, resonated with their own experiences in the field. Their validation of our analyses provided further support for our findings.

\section{Modes of Organizing Biomedical Innovation}

From the first-phase analysis, coupled with literature review, two broad dimensions were found to be helpful in characterizing innovation projects. We refer to these here as 'organizational coupling' and 'knowledge boundaries'. These dimensions are depicted 
in Figure 1 and described briefly next. Details on the derivation of these dimensions from the phase 1 data can be found elsewhere [reference to be added].

\section{INSERT FIGURE 1 ABOUT HERE}

Organizational coupling refers, then, to the organization and management of collaborations and network ties between partners. Variation along this dimension ranged from networked and loosely coupled modes, to more hierarchical and tightly coupled modes (cf. Alter and Hage, 1993; Hardy et al, 2003; Owen-Smith and Powell, 2004). In the former, innovation projects were pursued by partners joined in a loosely coupled network of organizations, with work being conducted across several organizations, each of which had significant autonomy in the management of their own work. Allocation of resources to tasks (including people, equipment and finances), where discussed, was negotiated through largely informal means. Thus management in such projects was decentralized and vertical dependency on centralized resources was low (Alter and Hage, 1993). Commitment to tasks was based primarily on mutual trust and obligation to a super-ordinate goal (e.g. producing a breakthrough new treatment) and promises of expected return, rather than on detailed or formally binding contracts. Where formal contracts did exist, these centred broadly on mutual obligations and the allocation of future financial gains (e.g. split of revenues generated). Knowledge flows could be described as occurring via relatively ‘open channels’, characterized by diffuse linkages \& 'knowledge spillovers' (Owen-Smith and Powell, 2004).

In contrast, in tightly coupled modes, most innovation activity was carried out and coordinated within a large focal firm but with clearly identified parts of the work (e.g. 
manufacturing, clinical trials) being formally contracted to other parties. Management was relatively hierarchical and there was high dependency on centralized resources, knowledge flows occurring via closed ‘conduits', or pipelines (Owen-Smith and Powell, 2004). Legally binding contracts existed to secure deliverables and protection of IP and detailed financial responsibilities and returns as well as the allocation of tasks, deadlines, roles responsibilities, risk management and so forth.

The knowledge boundaries dimension relates specifically to ways in which knowledge was combined across the different specialist domains involved and ranges from 'high' to 'low'. It is important to emphasize here that, in keeping with a constructivist approach, we saw knowledge domains not as purely cognitive, but as tied to boundaries of specialized practice (Carlile, 2004; Orlikowski, 2002). Nearly all biomedical projects discussed in phase 1 deployed multidisciplinary teams and so spanned cognitive domains - different forms of knowledge (scientific, commercial, clinical, regulatory) clearly needed to be brought together in development (Howard-Grenville and Carlile, 2006; Gay and Dousset, 2005). The important issue here, then, was not simply multidisciplinarity, but whether or not the work involved in innovation projects actually demanded new ways of practicing across these domains that meant that existing knowledge/practice boundaries had to be overcome.

High knowledge boundaries arose in situations where there were high novelty areas involved, where medical need was ambiguous and/or contested and where implications for clinical practice were difficult to forecast (Carlile, 2004). In such projects the intensity of knowledge sharing between those involved in upstream science (e.g. scientific research) and those involved in downstream application (e.g. clinical practice) 
was greater. An example of such a situation was the development of tissue engineered products, which required the progressive transformation and blending of knowledge, expertise and artifacts across existing disciplines and occupations (Bock et al, 2003). High knowledge boundaries also arose in situations where the parties involved needed to combine their expertise, in order to articulate new knowledge and practices, but had not worked together before or, indeed, with others in those particular disciplines or occupations - for example, when each organization had a 'piece' of technology, or IP, and only the combination of the pieces would allow the development of the product. These kinds of situation engendered 'pragmatic boundaries' (Carlile, 2004), meaning that alignment of professional interests and development of shared expectations among stakeholders was crucial.

The combination of these two dimensions provided a novel framework for understanding characteristically different modes of organizing innovation projects, depicted in the four quadrants of Figure 1. In the next section these different kinds of innovation project are described and illustrated through case descriptions. Whilst our analysis, as seen, drew from all 10 cases, we have elected, due to pressures on space, to focus here on 6 to illustrate these (3 UK, 3 US). We also focus on the projects represented by Quadrants I, III, and IV. Whilst we collected ‘vignettes’ of Quadrant IItype projects from the first phase, our cases studies were not concentrated here because these examples were typically centred on more traditional, incremental innovation processes contained within the R\&D departments of large global pharmaceutical firms, with technology being either developed in-house, bought or licensed. Whilst these kinds of innovation project are interesting in their own right, they are considered less relevant 
to our main area of interest (i.e. the link between innovation processes at project level and a nations’ capabilities ).

\subsection{Quadrant I Cases}

Quadrant I, characterized by loosely coupled organizational relationships and low knowledge boundaries, was typically populated by small early stage spin-off companies started by academics with entrepreneurial interests and/or commercial experience. There was high dependency on the parent university or PRO (Powell et al, 1996) and multiple sources of funding were sought for facilities, equipment, consumables and specialist expertise (e.g. from research grants, venture capital investors and larger biotechnology or pharmaceutical firms). However, the development of the science and technology required relatively low levels of knowledge integration across those groups involved, knowledge being produced in sub tasks performed more or less separately and pooled subsequently (Thompson, 1967). Innovations here did promise significant improvements in treatment, but were minimally disruptive to existing modes of treatment delivery and so did not depend centrally on combining the production of the science or technology with the particular expertise of clinicians that would likely deploy it (Christensen, 2000).

NewPharma was a start up based in the US developing a new therapeutic for a neurological disease based on the founding academic’s discovery in his Hospital lab. The company was established with personal funding from the founders, the scientist who made the original discovery and an 'entrepreneurial' partner who took the role of CEO. The three had previous experience of launching a company together. The founding scientist did not take an operational role in the company but served as a 
member of the management and scientific advisory boards. Whilst he viewed himself as a 'risk taker', there was an express awareness of the limits to which he could engage in commercialization activities and still retain his academic position.

NewPharma obtained a licensing option from the Hospital (who held the patent) with a view to following one of two options: license their compound to a pharmaceutical company or develop it within NewPharma. They delivered presentations to senior pharma executives and research scientists with links to pharmaceuticals. Where individuals appeared to be interested, they were invited to help NewPharma negotiate licensing deals with pharmaceutical companies with which they had connections, in return for shares in the company. These 'deal breakers' were essential to get access and credibility with potential investors in pharmaceutical companies. Simultaneously there was a need for validation of the discovery by academic peers. This was to be achieved by submitting a paper to a reputable journal. During the period of the study, NewPharma was unsuccessful in getting investment. Based on feedback they received from the presentations that expressed concern that a single discovery was not a sufficient platform to attract investment, NewPharma continued to search for a partner with additional patents to build a platform.

SampaTech was a small company developing novel therapeutics for hepatitis. It was founded by two scientists from a leading UK university, who developed the basic technology in collaboration with a large pharmaceutical firm (that subsequently withdrew from the project) and another university. By early 2005, the company had acquired two rounds of seed funding: one from one of the universities and another from a donation. The intention was to develop the lead project, out-license it and use the 
royalties for further developments. SampaTech had a loosely coupled management structure, relying on a number of part-time executives and administrative personnel, coordinated by one of the two founding scientists (who continued their academic activities at the university). Although the academic Director had a history of interaction with industry, via involvement on the advisory boards of biotechnology companies, the company still relied heavily on the technology transfer office of the university, which provided access to biotech companies and the VC community.

SampaTech’s first CEO had formerly worked as a manager in a large pharmaceutical firm but was later considered to lack the scientific background required to secure further VC funding. A new CEO was appointed, with the help of the technology transfer office, who had 'the right' profile. She had previously started several biotechnology companies thereby developing a reputation as a 'serial entrepreneurial scientist'. This change of CEO resulted in a major refocusing of the organization strategy, which was initially geared towards the development of three technology platforms, thereby requiring extensive funding. By reassessing the strategy, the new CEO narrowed the area of development to therapeutics, thereby generating external pharmaceutical interest in licensing the lead product.

\subsection{Quadrant III Cases}

The projects in Quadrant III, like those in Quadrant II, were usually led by larger biotechnology or pharmaceutical firms. However, whereas Quadrant II, projects were aimed at incremental improvement of currently available treatments, Quadrant III describes cases where the companies ventured into highly innovative areas where the development of breakthrough technologies placed high demands on the focal 
organization to collaborate with basic researchers and, given their potential to disrupt medical practice, also required constant interaction with (and input from) end users (health professionals) and regulatory bodies. These innovation projects were managed centrally, based on formal contractual agreements with smaller companies and specialist research organizations in ways reminiscent of supply chain interactions. However, whilst inter-organizational relationships and financial resources were tightly controlled by the central organization, knowledge was widely distributed and needed to be brought together across different domains of practice.

AmericanBio was a relatively large US biotechnology company. ELBOW was a product for cartilage repair based on tissue engineering technology. The ELBOW project was conducted by a multifunctional core team. Importantly, AmericanBio had a strong internal regulatory group responsible for interaction with the FDA. This regulatory expertise was crucial for ELBOW, since initially there was no regulatory framework and AmericanBio were able to shape the regulations to secure approval for their first generation product. Besides the challenges involved in regulation, sales and marketing had also proven costly and complex as the product disrupted established ways in which orthopedic surgeons (the main users) practiced. Thus, development required a significant degree of interaction with the user community.

Currently, AmericanBio is developing a new generation of ELBOW. Setbacks with its internal development prompted the decision to search for external technology that could help 'leapfrog' the project through early stage clinical trials. The company had a special interest in EU companies, because the lack of regulation of tissue engineered products in Europe meant that patient data on the technology was available that might help ease 
the progression to clinical trials in the US (interestingly, while AmericanBio had played a major role in shaping US regulation, which made it difficult for competitors to enter the market, they now had to face those same regulatory barriers to develop their own new generation product). AmericanBio identified and acquired a company in Europe which had the technology needed and initial clinical data. One important criterion in their selection was a match in terms of organizational cultures. AmericanBio had earlier carried out diligence on another company, but decided not to acquire it because of 'significant organizational differences'. Following the acquisition, meeting timelines in product development proved difficult, one of the reasons being that the clinical data wasn’t as ready for FDA approval as expected, despite the fact that AmericanBio had conducted a very thorough due diligence process and, according to one respondent, 'knew where to look for dead bodies'.

Body was based in the UK and developed its business based on expertise in producing human antibodies. ANTIBODY-2 is a project concerning development of a therapeutic antibody for inflammatory disease. During early stage clinical trials, Body decided to out-license ANTIBODY-2, because they did not have the resources for later stage trials that would necessitate large patient populations. The anticipation of the future partnering arrangement had a significant impact on Body's decisions about the design of their early stage trials. A major issue was in estimating what risk to accept for an expected return from the partnering arrangement, that was yet to be agreed. The more robust the efficacy evidence for ANTIBODY-2, the better the financial deal with a partner; but more trials would entail greater costs and there was always a risk that the results might not prove favourable. 
Pharmaceutical companies who expressed an interest in partnering were given an information pack about the project produced by Body's project team. Whilst these firms were conducting their own due diligence projects, they were also expected to deliver 'capability presentations' outlining the sorts of trials they planned to conduct to progress the project and the resources they would commit. This was because Body wanted to be confident that the partner would have sufficient knowledge and resource to move forward with ANTIBODY-2 and take it to market quickly. Within Body, there was a lot of informal personal networking across the various teams involved and with outsiders - as one respondent noted 'everybody in this industry knows everybody’. However, the decision was made to exclude from partnering discussions anyone involved in existing relationships with the candidate companies. In this way, formal networks were emphasized and information management during due diligence was deemed crucial.

\subsection{Quadrant IV Cases}

Quadrant IV also contains projects in highly novel innovative areas that could break regulatory grounds and were likely to disrupt healthcare practice (Christensen, 2000). The novelty of the technology, or combination of technologies, typically generated an informal inter-organizational web of smaller companies and collaborating PROs. One practitioner observed that these 'sexy technologies' created an 'aura of attraction' that drove interest and collaboration. These innovations typically depended on highly networked individuals to orchestrate loosely coupled, decentralized projects and innovation relied heavily on the co-production of knowledge across varied domains of specialist practice. Reflecting this tasks could be described as fully, or reciprocally, interdependent, where the sub-tasks continuously interacted because the knowledge, 
outputs and decisions from one had a direct impact on the others, and rewards were groups-based (Thompson, 1967; Wageman, 1995).

DiagnosticLabs was a small US company specializing in diagnostic assays that initiated a development project to transform them into a 'theragnostic' company, combining diagnostic and therapeutic products. The logic was that availability of a targeted drug would increase the market for their diagnostic and vice versa. This project was championed by their recently appointed CEO, who had a reputation for managing successful biotech companies. The choice of a specific disease as an initial area for development, characterized by a high mortality rate and no approved treatment, also reflected medical need. The new project built upon an existing diagnostics kit for this disease, which was being developed by DiagnosticLabs through collaboration with academic partners. DiagnosticLabs lacked clinical trials and regulatory expertise and so, via the CEO’s personal networks, formed an alliance with Bioclinical, a company specializing in clinical trials consulting and services, which provided a dedicated team to lead the clinical trials.

The CEO used her personal connections to identify a company TherapeuticCo that held IP for the matching therapeutic. She originally believed that this IP was supported by sufficient pre-clinical data to allow the project to go straight into clinical trials. Bioclinical conducted a due diligence assessment of TherapeuticCo's IP on a 'good will' basis and concluded that the preclinical data available would not be sufficient to gain FDA approval for clinical trials and to convince VCs to provide the investment needed. TherapeuticCo was not interested in making additional investments in a noncore area and a newly-appointed CEO at the company did not want to dedicate further 
time to the project. In addition, DiagnosticLabs’s owner decided to sell the company, so halting new investment. On top of this, there was a break down in the relationship between the CEOs of DiagnosticLabs and Bioclinical, as the Bioclinical team realized that DiagnosticLabs was pushing for VC money for themselves and not for the project alliance. As a result, the development project was abandoned.

NewTissueCo was a spin-out company from TEC - a leading tissue engineering research centre in the UK based at a university hospital. It had preferential rights to exploit TEC's technologies to make 'scaffolds' on which to grow stem cells and, potentially, new organs and bones. This field is extremely novel with potential applications in the long term. NewTissueCo was established by two highly regarded and experienced scientists with the help of the university's business development office and seed corn funding. Although the original intention had been to find funding for the commercialization of tissue-engineered products, the lack of VC interest in this longerterm vision led to a shift in emphasis towards the exploitation of existing IP through licensing deals with biotech companies that would enable the generation of revenues to fund other, riskier projects.

Originally the company was managed by two former executives of large pharmas and operated as a virtual company employing a small number of part-time consultants. By 2004, a new CEO was appointed who had extensive experience in the relevant scientific and commercial fields, including business start-ups. Recently, NewTissueCo had established a commercial licensing deal with a larger company, BiotechCo, and had also attracted further VC funding. The company was also involved in a number of research collaborations with TEC scientists, involving grant applications to various UK 
government and international funding bodies. With these developments, the new CEO was able to recruit new full-time staff and start investments in production facilities to support the licensing deal.

The continued engagement of the lead 'star scientists' involved in setting up NewTissueCo had important reputational and social capital effects, as well as important practical and political effects in keeping the company well connected to leading scientific teams and attuned to the politics of the host university. Close internal connections within the university also lent scientific credibility to dealings with external commercial partners - creating a symbiosis between scientific and commercial interests. Importantly, networking not only involved developing relationships with and through the principal scientists, but also with researchers working within their teams, including PhDs, who could potentially assist with generating new IP and commercialization.

\section{Mechanisms Linking Innovation Processes to Macro Capabilities}

Tables 1 and 2 summarise the mechanisms found in our cases to be important in enabling the innovation process for different kinds of project (recognising, as discussed, that what counted as 'success' was interpreted differently across projects), grouped in our analysis terms of how they related to integrative or relational capabilities.

Insert Tables 1 and 2 around here

\subsection{Integrative capabilities}

Firstly, our findings echo earlier work by highlighting the importance of access in projects to individuals who work 'at the interstices' of science and commerce in order to 
acquire relevant knowledge and expertise and to build the skills base (Powell et al, 1996; Murray, 2002; Casper and Murray, 2005). For example, in DiagnosticsLabs, the opportunity to develop a 'theragnostic' was identified by the CEO - an experienced biomedical entrepreneur who also had close networks with PROs. Other research suggests that this mechanism is shaped by a nation's integrative capabilities, which reflect differences in labour market institutions. For example, in her study of innovation in tissue-engineered cartilage, Murray (2002) found that the commercialization of science into new medical treatments depends crucially on overlapping, but distinctive, scientific and technological networks at the institutional level. Connections to scientific networks, via key individuals who work at the interstices of such networks, provide 'knowledge spillover' effects that shape technological progress and influence firms' abilities to develop intellectual capital (Zucker et al 1998). This finding echoes earlier research on the important role of 'boundary spanners' who broker relationships across networks (e.g. scientific and commercial) and facilitate the transfer of knowledge across contexts (Tushman and Scanlan, 1981; Carlile, 2002). Having access to individuals who work at the interstices of science, commerce and the clinic also played an important role in increasing the 'absorptive capacity’ of our case firms, by improving their ability to recognize new information, assimilate it, and apply it to commercial ends (Cohen and Levinthal, 1990). There were a variety of ways in which our case companies gained access to people working at the interstices of networks: through establishing links with academics (as in DiagnosticLabs), by enlisting ‘deal breakers’ to participate in negotiations with potential partners (as in NewPharma), by training PhDs who could retain links with research groups and, at the same time, assist in commercialization activities (as in NewTissueCo) and, where PROs were involved, relying on a university technology transfer office to access networks (as in SampaTech). 
Another crucial mechanism was having members of projects with scientific and commercial credibility in order to attract VC investment and/or major research funds. In NewTissueCo and SampaTech, for example, the choice of CEO with the 'right' scientific profile and track record with investors was critical. This credibility appears to be easier to establish in the US context and particularly in the Boston region (where our cases focused) where there is a strong history of successful biotechnology ventures and VC investment (McMillan et al, 2000). Whilst not stressed in research on innovation and networks, this dual orientation does resonate with research on how VC operates. Zider (1998), for example, found that the reputation of entrepreneurs plus their business track record and 'presentability' to outside investors, is as, if not more, important in attracting funding as their knowledge base or particular ideas; this he argues helps to explain US superiority in VC markets. According to Zider (1998, p. 138): “Many entrepreneurs make the mistake of thinking that venture capitalists are looking for good ideas when, in fact, they are looking for good managers in particular industry segments”.

Another way of establishing credibility for investment is via the scientific publication records of the biotechnology firm's scientific team (Deeds et al, 1997). In NewPharma, for example, those involved believed publication in a reputable scientific journal was crucial for public validation. Furthermore, the affiliations founders had with other organizations were also important for increasing credibility. This finding echoes work by Higgins and Gulati (2003) who demonstrated that the affiliations that senior managers of biotechnology firms held with other organizations had an important symbolic value for prestigious investment banks when deciding whether to support 
initial public offerings. The greater the prestige of the relationships, the higher the valuation - and hence private funding - a firm could command and so the greater the likelihood of an innovation reaching development. Across our cases, such affiliations appeared to be easier to establish in the US, for example, with academic scientists more frequently on the Scientific Boards of prestigious pharmaceutical or biotech companies. This is consistent with the finding that integrative capabilities encouraging movement across scientific, clinical and commercial domains is stronger in the US (Owen Smith et al, 2002). The idea of a firm's reputation-building practices providing legitimacy for investors is also supported in recent research by Nicholson et al (2005), who demonstrated that biotechnology firms took a substantial discount on their first outlicensing deals with large pharmaceutical firms, which was then quickly recouped through significantly higher valuations from VC at subsequent financing rounds.

The importance of reputation building and the symbolic value of affiliations relates closely to another mechanism identified in our cases, which was the symbolic role played by 'Figureheads' - usually lead scientists with international reputations and commercial and/or clinical experience. Such individuals, when linked closely to projects, played a key role in mobilizing support amongst diverse users and clinicians. For example, the lead scientist in NewTissue embodied (quite literally, having been a former patient himself as well as a lead clinician) the overall vision of the project, symbolizing its clinical and scientific significance to user groups. The importance of 'star scientists' has been noted elsewhere, but usually in terms of the role such individuals play in linking commercial activity to the knowledge base of academe (Zucker et al, 1998). Whilst this was important (and discussed above), here we use the term 'Figurehead' to highlight also their symbolic and motivational effects. We did not 
observe as many 'figureheads' in our US cases, nor was their importance emphasized as much by interviewees, suggesting that this mechanism may be particularly crucial in the UK context in bridging what were often more polarized values and perceptions of those engaged in academic, clinical and commercial practices (Mallon et al, 2005).

This leads to the final important mechanism, which concerned career perceptions and professional values of those working in PROs. There were two related issues here. The first concerned the extent to which scientists saw their careers in both scientific and commercial terms - that is, as ‘entrepreneurs' or, in Mallon et al’s (2005) terms, as ‘strategic opportunists’. In Sampatech, for example, scientists pursued commercialization for 'altruistic' reasons as a means to develop science, whereas in New Pharma the lead scientist described himself as 'a risk taker' and 'entrepreneur'. Other research has indicated that entrepreneurial values may be less widespread in UK academe. In a qualitative survey of UK scientists in PROs, Mallon et al, (2005) found that the majority had an over-riding sense that obvious commercial ambition was not quite acceptable within public sector science and so did not incorporate this into their career planning. Only a third - described as 'strategic opportunists' - were prepared to consider a move from 'the bench' to a commercial career, but most of this group had become aware of the opportunities because they had previous experience of working outside the public sector.

The second issue concerned the extent to which scientists perceived their professional values as scientists and clinicians to be aligned with, or potentially compromised by, the pursuit of commercial activity. In our cases, the actual movement of scientists from academe to commerce was rare. In all the cases where PROs were involved, the lead 
scientists remained as scientists, and recruited other people to push forward commercialization. However, there were important differences, reflected in the professional values of scientists across UK and US contexts. So, in NewPharma and DiagnosticLabs, for example, commercialization was seen as meaningful in its own right, both as a means to clinical improvement and as a way of generating personal revenue for the scientists. In contrast, in SampaTech and NewTissueCo, the major motivation was to 'make a real difference to patients lives' and to use this activity to help fund continued scientific development, not to make their personal fortune. This suggests that, at least in our cases, the mobility of individuals' careers across boundaries of science and commerce emphasized elsewhere (Casper and Murray, 2005) was less significant in incentivizing (or de-incentivizing) commercialization than the professional values that individuals attached to their work. One of the problems in the UK, is that individuals’ career perceptions are still quite polarized and scientific entrepreneurship less strongly advocated (Clark, 2000; Turpin and Deville, 1995; Mallon et al, 2005).

Finally, our analysis suggested that these mechanisms relating to integrative capabilities were more crucial in projects characterised by loose, rather than tight, organizational coupling. This can be explained in terms of two major impacts of a nation's integrative capabilities. First, such capabilities have an impact on the motivation of scientists to engage in commercialization, moving between academia and industry and connecting basic research and development. Thus mechanisms 1 and 4 were important ways in which this motivation was facilitated. They helped to orchestrate loose networks characterising projects in Quadrants I and IV and made possible different kinds of transactions (e.g. between key scientists, entrepreneurs and investors). Second, such 
capabilities have an impact on the ability to secure resources (e.g. from research funding, VC and through partnerships) needed to move innovation forward in situations where these resources are not available from and cannot be centrally controlled by one organization. Mechanisms 2 and 3 were important in this respect. In tightly coupled innovation projects there was less need to rely on such mechanisms because the R\&D was controlled from within larger biotechnology or pharmaceutical firms, which deployed internal resources and were populated by scientists who, given that they worked in a commercial environment, were directly incentivised to commercialize basic research. In this way, the analysis indicates that a nation's integrative capabilities might be expected to have relatively stronger effects on projects in Quadrants I and IV. Interestingly, these mechanisms were not simply focused on knowledge integration but, rather, were most important in terms of building the relationships across the academic/commercial communities in order to establish the reputation and claims to knowledge required to attract investment.

\subsection{Relational Capabilities}

Turning to relational capabilities, these concern how easy/difficult it is in the macro institutional context to establish and maintain collaborations across diverse organizations. At project level, alignment of interests and expectations was a crucial mechanism in our cases and can be linked to relational capabilities. Key to achieving this was the due diligence process. Where due diligence was two-way (conducted by each party involved), as in the Body case, projects were able to balance partner interests and commitments. Moreover, once a collaboration agreement was in place, it was important to have mechanisms to ensure continuous monitoring and allow early identification of potential misalignment of interests or expectations. This was achieved, 
for example in the Body and AmericanBio cases, by matching project structures and processes to partners so that issues and concerns could quickly be identified. Where this was not achieved, as in the DiagnosticLabs case, the collaboration quickly broke down. Other research has also identified that the alignment of interests and expectations between partners is crucial for innovation involving collaboration between biotechnology firms and pharmaceutical firms (Rhodes et al, 2003). As Rhodes et al put it: "the process of partner identification should not be undertaken opportunistically” (p. 300).

A second mechanism linked to relational capabilities that was important at the project level was the ability to build upon existing inter-organizational networks to generate resources and buy-in from users (i.e. clinicians). This links to recent literature on innovation ecosystems (Adner, 2006) that identifies the importance of building markets as well as 'brilliant products'. Moreover, it is clear that users can contribute to the development of the product itself (Lettl et al, 2006; Von Hippel, 2005). Enrolment (of users and resources) in our cases involved building from existing networks which then acted as a 'centre of gravity' for further networking and enrolment (Kreiner and Schultz, 1993). For example, AmericanBio’s acquisition of a European company gave it access, not only to that company' technology, but also to the network of influential clinicians and clinical data it had established. AmericanBio also committed significant resources to training clinicians in the new surgical techniques so that they could act as 'opinion leaders’ for their product in the clinical community (Rogers, 1995). NewTissueCo also capitalized on existing relationships by closing licensing deals and using these to leverage commercial viability and secure resources for their more long term and riskier core project. Furthermore, DiagnosticLabs used their CEO’s existing personal networks 
to conduct due diligence for free from Bioclinical, with the promise of future gains should the collaboration prove fruitful.

A third important mechanism was interaction with regulators, either directly to shape regulation and ensure approval (as in AmericanBio), or with other firms that had regulatory expertise and could help develop required documentation and interactions with the FDA (as in Body and DiagnosticsLabs). Given the uncertainty associated with treatments being developed in biotech companies, such collaborations were extremely important, with regulators (and regulations) acting as 'obligatory passage points' in networks (Callon, 1986). Many small biotech firms do not have this expertise (Hawthorne, 2005) and so are very dependent on specialized consultants to provide it.

Finally, our cases demonstrated the importance of having in projects a product 'magnet' to bridge organizations in the market place (Doz et al, 2001). Thus, in NewTissueCo, the 'revolutionary' nature of the innovation mobilized different stakeholders in the network and helped entice other organizations to want to work with the company on this 'leading edge' technology. In AmericanBio, ELBOW was a well developed but innovative product, where desired characteristics for the next generation were known in the user and business communities. Similarly, in DiagnosticLabs, the 'theragnostic' concept helped bring together different 'pieces of the puzzle'. When there was no clear product 'magnet' - for example, in cases with multiple possible indications derived from the same compound - the project could suffer from a lack of focus. Whilst product magnets are perhaps more closely linked to markets than networks, our data imply that they may help to generate activity and networking around particular areas of innovation, so potentially shaping (and being shaped by) relational capabilities. 
Our analysis suggested that these mechanisms were more crucial in those projects characterized by high knowledge boundaries (Quadrants, III and IV). This appeared to be because of the highly novel nature of the innovations in these projects and the very long innovation life cycles. This meant that there was a need to constantly leverage resources in order to support long term commercial developments. Moreover, for a project to be 'successful', it needed to deal with problems associated with the disruption to existing practices that these innovations could introduce. Our case projects used and built upon existing networks to generate and sustain resources and 'buy-in’ (Mechanism 6) and to ensure approval (Mechanism 7). Furthermore, the nature of these innovations meant that knowledge integration in the context of complex inter-organizational dynamics was crucial. Such projects encountered, in Carlile’s (2004) terms, political or ‘pragmatic’ boundaries. Aligning interests and expectations (Mechanism 5) and having a strong product magnet (Mechanism 8) was helpful in terms of dealing with such pragmatic boundaries. While projects in Quadrants I also involved collaboration with other organizations (e.g. technology transfer offices or investors) their main challenge was to develop their credibility across the scientific/commercial divide; knowledge integration per se was less important. Interestingly, then, the mechanisms we identified that we argue link to relational capabilities were more focused on ways in which relationships could foster knowledge integration by overcoming pragmatic boundaries, rather than on building the relationships per se (Carlile, 2004).

\section{General Discussion and Conclusions}

This study has explored how macro-level capabilities relate to micro biomedical innovation processes, focusing on integrative and relational capabilities found to be 
important in the biomedical domain (Owen-Smith et al, 2002). This builds from earlier research that has shown how institutions governing labor, finance and product markets affect innovation activities and the performance of sectors and nations (Nelson, 1993; Hall and Soskice, 2001; Clark 1987). A main contribution has been to identify and unpack mechanisms (depicted in Tables 1 and 2) that appear crucial in helping to explain how macro-level capabilities play out at the level of micro-level innovation projects. These mechanisms are not exhaustive but provide a useful starting point in terms of understanding the processes through which macro capabilities may come to influence innovation processes.

It is worth noting that the mechanisms identified played a role in shaping innovation processes but may also be shaped by them. For example, having scientific and commercial credibility with investors both influenced innovation processes (by attracting funding) but was also influenced by them (past 'successes' generating credibility, for example). Moreover, whilst we did not address this in our study, these mechanisms might influence, as well as be influenced by institutional arrangements and capabilities. For example, prior research has found that labor markets and integrative capabilities at the macro level influence individuals’ career perceptions and mobility, but that this relationship is recursive since they are also influenced by them (Casper and Murray, 2005). Moreover, these mechanisms work together in innovation processes, not in isolation. For example, in NewTissueCo a strong figurehead role was coupled with complementary commercial expertise and a relatively strong product magnet which allowed the project to secure further funding, despite the overriding suspicion of commercially oriented activity by the UK founder. 
Where previous work has focused on benefits of macro capabilities in terms of knowledge flows, our data suggest that issues of credibility, values and perceptions, and alignments of interests are equally, if not more, important in terms of mobilizing innovation at the project level. Yet, most policy initiatives aimed at encouraging innovation in life sciences (e.g. technology transfer, network grants, joint patents and so forth) focus on knowledge flows/knowledge transfer between public and private organizations. Our study suggests that the effects of these initiatives may be limited if attention is not also given to the normative mechanisms highlighted here. In the UK context, where scientific, clinical and commercial interests are more clearly demarcated (Clark, 2000), these latter, normative, concerns become even more central than in the US, where the hybridization of scientific, clinical and commercial values is generally more acceptable (Clark, 2000). To extend a construction metaphor, in the UK, building bridges allow knowledge to flow between PROs, commercial and clinical organizations may be problematic because the ends of the bridge may be substantively different.

A second contribution is to consider the relative importance of macro capabilities at the institutional level for characteristically kinds of innovation projects. Thus we can propose that the influence of institutionalized capabilities on innovation process at the micro level is systematically related to different modes of organizing innovation. Whilst our inductive methodology allows us to generate this proposition, future research would be needed to confirm (or refute) it. However, our analysis suggests, in line with other theorists, that institutional arrangements do not determine innovation processes but may, as Clark (2000) puts it, generate 'zones of manoeuvre' that allow some kinds of activities to occur more easily than others. Moreover, it suggests that the relative disadvantages of being in an institutional context (the UK) that is less supportive of 
integrative and relational capabilities can be overcome where mechanisms of the kinds we have identified can nevertheless be developed (in NewTissue, for example). Similarly, whilst Mallon et al's (2005) study of UK scientists in PROs found the majority to be uncomfortable with coupling scientific and commercial ambition, a significant minority (the 'strategic opportunists') were prepared to move between 'the bench' and a commercial career.

This suggests that generic statements about relative national advantage in biomedical innovation need to be tempered by a consideration of the kinds of project and the combination of mechanisms deployed at project, firm or sector levels (Casper and van Waarden, 2005). The framework depicted in Figure 2 attempts, then, to provide further insights into the relative advantage/disadvantage of particular national contexts for innovation. Thus, our analysis suggests that innovation processes in lower left part of Figure 2 (Quadrant II) are less affected by macro capabilities and so we may not expect significant differences across US and UK contexts for this mode. In Quadrant II, innovation projects are dominated by large pharmaceutical firms, which operate on a global basis. Arguably, then, national institutional contexts might play a less important role here, as compared with the features of the particular lead organizations, which have a relatively high degree of autonomy and control (Hardy and Phillips, 1998; Hardy et al, 2003).

\section{INSERT FIGURE 2 ABOUT HERE}

On the other hand, projects characterized by the upper right part of Figure 2 (Quadrant IV) are likely to be most affected by macro capabilities of the particular institutional 
context in which they operate. Here, mechanisms relating to both integrative and relational capabilities appear to be important in order to orchestrate loose relationships and bridge knowledge boundaries, meaning that stronger differences in innovation performance would be expected between the UK and US for these kinds of projects. While we do not have comparative data per se that would allow us to confirm that these types of project were less frequent and less successful in the UK as compared to the US, our 1st phase survey data did indicate that a greater instance of Quadrant IV type innovation projects in the US than in the UK, and more problems associated with such projects in the UK context. Whilst, the case of NewTissue showed that Quadrant IV type projects in the UK could survive, we would predict that it would take considerably more effort to develop appropriate mechanisms at project level to cope with the challenges of networking across the academic/commercial divide and building organizational collaborations in this context. We would anticipate, then, that Quadrant IV type projects would be more problematic in the UK context and might move more rapidly than their US counterparts, to another quadrant where the macro-institutional context has less of a divisive impact. Again, this is something that future empirical research could more directly evaluate.

In the middle part of Figure 2 (Quadrants I and III) we expect moderate effects of the macro capabilities - they matter but perhaps not enough to produce systematically large differences across the US and UK contexts. For example, for Quadrant I, where integrative capability has more importance, specific initiatives can be built to cope with the more rigid divide between academia and industry in the UK context, for example by introducing policies that direct TTO’s activities to assist spin-off companies and scientists in their participation within loose networks (as described in the case 
examples). In Quadrant III, where relational capability has more importance, innovation projects are conducted within larger organizations, and of course some UK-based firms can be as experienced as US-based firms in developing the required collaborations.

This kind of analysis extends existing research that treats the impact of integrative and relational capabilities on innovative performance in the biomedical sector as, in broad terms, uniformly positive (Owen-Smith et al, 2002), by suggesting that their impact may be more acute for some kinds of project than others. Our study also helps to address a central critique of comparative institutional studies concerning, as Casper and Murray (2005; 56) put it (in relation to labor market institutions), "the limited connection made between macro-institutions and the micro-dynamics (of individual careers) through which these institutional differences are manifested”.

Before discussing the implications for policy, there limitations that should be dealt with. First, this is an exploratory study using a limited number of firms and projects; therefore, we cannot generalize our findings to the larger population of firms and projects. Whilst we can suggest contingencies between the impact of macro capabilities and different kinds of projects, the propositions developed here require further research on a broader sample of development projects in the UK and US. Second, whilst our framework is useful in identifying patterns of innovation, it is clearly broadly-based and more fine-tuned analysis of particular modes would no doubt be able to identify further variation in the organization of biomedical innovation (Lockett et al, 2005). It should also be noted that innovation processes are not confined to particular 'boxes' - they may shift modes across their lifecycle. For example, if tissue engineering does eventually establish itself as a professionally demarcated 'discipline', then innovation 
projects could shift to quadrants with characterised as low in knowledge boundaries. Third, whilst our classification of mechanisms in terms of whether they link to integrative or relational capabilities is useful for analytical purposes, clearly integrative and relational capabilities are themselves related concepts (both being linked to network ties, for example). Thus, feasibly, some mechanisms might relate to both capabilities to a greater or lesser extent. Further work would be required to tease our these interrelationships and test further our initial propositions.

Turning finally to policy implications, this study suggests a need for national policy aimed at improving biomedical innovation to be sensitive to the different ways of organizing innovation identified here. Taking these implications further, it suggests potential perverse effects of, supposedly supportive, policy initiatives for knowledge transfer. For example, in the UK, government policies aimed at helping academic scientists to switch to industry careers (e.g. by starting up businesses) or university policies which allow academics to engage in a specified number of days' consultancy 'outside' of their academic work, may actually serve to reinforce the fundamental gap between academic and commercial values and career interests. More important in the UK context, might be to develop more normatively-based initiatives and incentives that encourage, for want of a better term, 'strategic opportunism' to become a more legitimate part of academic practice (Mallon et al., 2005). Such initiatives might include, for example, industry secondments of doctoral students or incentives for academic scientists to participate in commercial scientific advisory boards. Finally, our results suggest that attempts to replicate US policy are unlikely to be fully effective in the UK context. For example, the UK Department of Trade and Industry (DTI), together with UK research councils, are keen to replicate 'MIT-type' institutional mechanisms to 
support innovation research (e.g. through initiatives such as the Cambridge-MIT Institute and the 'Innovation Challenge'). However, as seen, the UK context may not support the hybridization of professional and occupational practices seen in the US, or the development of scientific entrepreneurs, required to make such a model work. 


\section{References}

Adner, R., 2006. Match your innovation strategy to your innovation ecosystem. Harvard Business Review 84(4), 98-107.

Aldrich, H., 2000. Organizations Evolving. Sage, London.

Alter, C., Hage, J., 1993. Organizations Working Together. Newbury Park, CA, Sage.

Alvesson, M., Skoldberg, K., 2000. Reflexive Methodology: New Vistas for Qualitative Research. Sage Publications, London.

Bock, A-K., Ibarreta, D., Rodriguez-Cerezo, E., 2003. Human tissue-engineered products: Today's markets and future prospects. Report published by the Institute for Prospective Technological Studies.

Callon, M., 1986 Some elements in a sociology of translation: domestication of the scallops and fisherman of St. Brieuc Bay. In J. Law (ed), Power, Action and Belief. London: Routledge.

Carlile, P. R., 2004. Transferring, translating, and transforming: an integrative framework for managing knowledge across boundaries. Organization Science 5(5), 555-568.

Carlile, P., 2002. A pragmatic view of knowledge and boundaries: boundary objects in new product development. Organization Science 13, 442-455.

Carlsson, B. (Ed.), 2002. Technological Systems in the Bio Industries: An International Study. Kluwer Academic Publishers, Boston.

Casper, S., 2000. Institutional adaptiveness, technology policy, and the diffusion of new business models: the case of German biotechnology. Organization Studies 21, 887-914.

Casper, S., Kettler, H., 2001. National institutional frameworks and the hybridization of entrepreneurial business models: The German and UK biotechnology sectors. Industry and Innovation 8, 5-30.

Casper, S., Murray, F., 2005. Exchange under conflicting institutional logics: commerce and science in the world of population genetics. Unpublished manuscript.

Casper, S., van Waarden, F., (Eds.), 2005. Innovation and Institutions: A Multidisciplinary Review of the Study of Innovation Systems. New Horizons of the Economics of Innovation series. Edward Elgar Publishing, Cheltenham.

Christensen, C. M., 2000. The Innovator’s Dilemma. Harper Business, New York. 
Clark, P., 1987. Anglo-American Innovation. De Gruyter, New York.

Clark, P., 2000. Organizations in Action: Competition Between Contexts. Routledge, London.

Clark, P., 2003. Organizational Innovations. Sage, London.

CMR International, 2006. Centre for Medicines Research International Pharmaceutical R\&D Factbook, CMR International, Surrey.

Cohen, W. M., Levinthal, D. A., 1990. Absorptive capacity: a new perspective on learning and innovation. Administrative Science Quarterly 35(1), 128-152.

Coombs, R., Harvey, M., Tether, B. S., 2003. Analyzing distributed processes of provision and innovation. Industrial and Corporate Change 12 (6), 1125-1155.

Deeds, D.L., Decarolis, D. and Coombs, J., 1997. The impact of firm-specific capabilities on the amount of capital raised in an initial public offering: Evidence from the biotechnology industry. Journal of Business Venturing, 12(1), 31-46

Denzin, N. \& Lincoln, Y., 1998. 'Entering the field of qualitative research', in N. Denzin \& Y. Lincoln (Eds), Strategies of qualitative inquiry, pp 1-34, London, Sage.

Dodgson, M., Gann, D., Salter, A., 2004. Innovation technology: exploring the impact of simulations on the innovation process. Paper presented at DRUID summer conference. Industrial Dynamics, Innovation and Development, Helsingore, Denmark.

Dopson, S., 2005. The diffusion of medical innovations: can configurational sociology contribute? Organization Studies 26(8), 1125-1144.

Doz, Y., Santos, J., Williamson, P., 2001. From Global to Metanational: How Companies Win in the Knowledge Economy. Harvard Business School Press, Boston.

Gay, B., and Dousset, B., 2005. Innovation and network structural dynamics: study of the alliance network of a major sector of the biotechnology industry. Research Policy 34, 1457-1475.

Gibbons, M., Limoges, C., Nowotny, H., Schwartzman, S., Scott, P., Trow, M., 1994. The New Production of Knowledge: The Dynamics of Science and Research in Contemporary Societies. Sage, London.

Gittell, J. H., Weiss, L., 2004. Coordination networks within and across organizations: a multi-level framework. Journal of Management Studies 41(1), 127-153. 
Glaser, B., 1978. Theoretical sensitivity: Advances in the methodology of grounded theory. Sociology Press.

Hall, P.A., Soskice, D. (Eds.), 2001. Varieties of Capitalism: The Institutional Foundations of Comparative Advantage. Oxford University Press, Oxford.

Hardy, C., Phillips, N., 1998. Strategies of engagement: lessons from the critical examination of collaboration and conflict in an interorganizational domain. Organization Science 9 (2), 217-230.

Hardy, C., Phillips, N., Lawrence, T., 2003. Resources, knowledge and influence: the organizational effects of interorganizational collaboration. Journal of Management Studies 40 (2), 321-346.

Hawthorne, F., 2005. Inside the FDA: The Business and Politics Behind the Drugs that We Take and the Food that We Eat. Wiley, Hoboken, NJ.

Henderson, R., 1994. The evolution of integrative capability: innovation in cardiovascular drug discovery. Industrial and Corporate Change 3(3), 607-630.

Higgins, M., Gulati, R., 2003. The effects of upper echelon affiliations on underwriter prestige. Organization Science, 14(3), 244-263.

Hilton, T., Flanzer, J., Cartwright, W., Fletcher B., 2002. Resistance to innovation among US drug abuse treatment providers: When organizational knowledge interferes with organizational learning. Paper presented at the Organizational Knowledge, Learning and Capabilities Conference, Athens.

Howard-Grenville, J. A., Carlile, P., 2006, forthcoming. The incompatibility of knowledge regimes: consequences of the material world for cross-domain work. European Journal of Information Systems.

Kreiner, K., Schultz, M., 1993. Informal collaboration in R\&D: the formation of networks across organizations. Organization Studies 14 (2), 189-209.

Lettl, C., Herstatt, C., and Gemuenden, H. G., 2006. Users’ contribution to radical innovation: evidence from four cases in the field of medical equipment technology. R\&D Management. 36(3), 251-272.

Liebeskind, J. P., Oliver, A. L., Zucker, L., Brewer, M., 1996. Social networks, learning and flexibility: souring scientific knowledge in new biotechnology firms. Organization Science 7 (4), 428-443.

Lockett, A., Siegel, D., Wright, M., Ensley, M.D., 2005. The creation of spin-off firms at public research institutions: managerial and policy implications. Research Policy 34, 981-993. 
Mallon, M., Duberley, J., Cohen, L., (2005). Careers in public sector science: orientations and implications. R\&D Management 35(4), 395-407.

McMillan, G.S., Narin, F. and Deeds, D., 2000. An analysis of the critical role of public science in innovation: the case of biotechnology, Research Policy 29, 1-8.

Miles, M. B., Huberman, A. M., 1994. Qualitative Data Analysis, Cambridge University Press, Cambridge.

Murray, F., 2002. Innovation as co-evolution of scientific and technological networks: exploring tissue engineering. Research Policy 31, 1389-1403.

Nelson, R., (Ed.) 1993. National Innovation Systems: A Comparative Analysis. Oxford University Press, New York/Oxford.

Nicholson, S., Danzon, P., McCullough, J., 2005. Biotech-pharmaceutical alliances as a signal of asset and firm quality. Journal of Business 78(4), 1433-1464.

Nowotny, H., Scott, P., Gibbons, M., 2001. Re-Thinking Science: Knowledge and the Public in an Age of Uncertainty. Polity, Cambridge.

Orlikowski, W. J., 2002. Knowing in practice: enacting a collective capability in distributed organizing. Organization Science 13(3), 249-273.

Owen-Smith, J., 2003. From separate systems to a hybrid order: accumulative advantage across public and private science at Research One universities. Research Policy, 32, 1081-104.

Owen-Smith, J. Riccaboni, M., Pammolli, F., Powell, W., 2002. A comparison of US and European university-industry relations in the life sciences. Management Science 48(1), 24-43.

Owen-Smith, J., and Powell, W. W., 2004. Knowledge Networks as Channels and Conduits: The Effects of Spillovers in the Boston Biotechnology Community. Organization Science 15(1), 5-22.

Pettigrew, A. M., 1990. Longitudinal field research on change: theory and practice. Organization Science 1 (3), 267-292.

Powell, W., Koput, W., Smith-Doerr, L., 1996. Interorganizational collaboration and the locus of innovation: Networks of learning in biotechnology. Administrative Science Quarterly 41(1), 116-130.

Rasmussen, B., 2005 Pharmaceutical industry project. Working Paper Series, Centre for Strategic Economic Studies, Victoria University of Technology, February. 
Rhodes, I., Nelson, C., Berman, G., 2003. The key to successful collaborations: rigorous and independent due diligence. Journal of Commercial Biotechnology 9(4), 297305.

Rogers, E.M. 1995, 4th Edition. Diffusion of Innovations. New York: Free Press.

Rosenberg, N., Nelson, R., 1994. American universities and technical advance in industry. Research Policy 23, 323-348.

Salman, N., Saives, A-L., 2005. Indirect networks: an intangible resource for biotechnology innovation. R\& D Management 35(2), 203-215.

Saunders, M., Lewis, P. and Thornhill, A., 2000. Research methods for business students. FT, Prentice Hall.

Stake, R. E., 1995. Case studies, in: Denzin, N. K., Lincoln, Y. S. (Eds.), Handbook of Qualitative Research. Sage, Thousand Oaks,CA, pp. 236-247.

Stokes, D. E., 1997. Pasteurs Quadrant: Basic Science and Technological Innovation. Brookings.

Thompson, J., 1967. Organizations in Action, McGraw-Hill, New York.

Turpin, T., Deville, A., 1995. Occupational roles and expectations of research scientists and research managers in scientific research institutions. R\&D Management 25(2), 141-157.

Tushman, M. and Scanlan, T. 1981. Boundary spanning individuals: Their role in information transfer and their antecedents. Academy of Management Journal, 24, 289-305.

Tsoukas, H., 1989. The validity of idiographic research explanations. Academy of Management Review 14(4), 551-561.

Von Hippel, E., 2005. Democritizing Innovation. The MIT Press, Boston.

Wageman, R., 1995. 'Interdependence and group effectiveness', Administrative Science Quarterly, 145-180.

Whitley, R., 2000. The institutional structuring of innovation strategies: business systems, firm types and patterns of technical change in different market economies. Organization Studies 21(5), 855-886.

Whitley, R., 2003. Competition and pluralism in the public sciences: the impact of institutional frameworks on the organisation of academic science. Research Policy 32(6), 1015-1029.

Zider, B., 1998. How venture capital works. Harvard Business Review 76(6), 131-139. 
Zucker, L., Darby, M., Brewer, M., 1998 Intellectual capital and the birth of US biotechnology enterprises. American Economic Review 88, 290-306. 


\section{Figure 1. Modes of Organizing Biomedical Innovation}

Figure 2. The Importance of Integrative and Relational Capabilities for Modes of Organizing Biomedical Innovation

\section{PLEASE INSERT FIGURES FROM FILE}

\section{Table 1. Mechanisms Linked to Integrative Capabilities}

\begin{tabular}{|c|c|}
\hline Mechanisms & Examples From Cases \\
\hline \multirow{4}{*}{$\begin{array}{l}\text { 1. Access to } \\
\text { people working at } \\
\text { interstices to } \\
\text { acquire } \\
\text { knowledge \& } \\
\text { reproduction of } \\
\text { skills base }\end{array}$} & $\begin{array}{l}\text { SampaTech } \\
\text { Reliance on TTO network to establish commercial contacts }\end{array}$ \\
\hline & $\begin{array}{l}\text { NewPharma } \\
\text { Reliance on 'deal breakers' to help commercialize the potential product }\end{array}$ \\
\hline & $\begin{array}{l}\text { NewTissueCo } \\
\text { Reproducing the scientific/commercial through training and employing PhD students }\end{array}$ \\
\hline & $\begin{array}{l}\text { DiagnosticLabs } \\
\text { Linking to the academic community through collaborations to develop IP and to conduct } \\
\text { clinical trials }\end{array}$ \\
\hline \multirow{4}{*}{$\begin{array}{l}\text { 2. Establishing } \\
\text { scientific and } \\
\text { commercial } \\
\text { credibility in } \\
\text { order to ensure } \\
\text { funding through } \\
\text { partnering, VC or } \\
\text { research funds (as } \\
\text { there are no } \\
\text { 'centralized' } \\
\text { resources } \\
\text { available) }\end{array}$} & $\begin{array}{l}\text { SampaTech } \\
\text { Selecting a CEO with the right profile in order to sustain connections and dialog with } \\
\text { pharmaceutical companies }\end{array}$ \\
\hline & $\begin{array}{l}\text { NewPharma } \\
\text { Persistently trying to publish in Science in order to 'validate' science in the eyes of potential } \\
\text { investors }\end{array}$ \\
\hline & $\begin{array}{l}\text { NewTissueCo } \\
\text { Importance of the role of the scientific founders and host university in providing scientific } \\
\text { credibility }\end{array}$ \\
\hline & $\begin{array}{l}\text { DiagnosticLabs } \\
\text { CEO has credibility within the VC community based on previous entrepreneurial experiences }\end{array}$ \\
\hline \multirow[t]{2}{*}{$\begin{array}{l}\text { 3. Symbolic } \\
\text { figureheads }\end{array}$} & $\begin{array}{l}\text { SampaTech } \\
\text { No figurehead involved and so the company relied heavily on the TTO to move the company } \\
\text { forward }\end{array}$ \\
\hline & $\begin{array}{l}\text { NewPharma } \\
\text { No figurehead scientist involved, which acted as a limiting factor }\end{array}$ \\
\hline
\end{tabular}




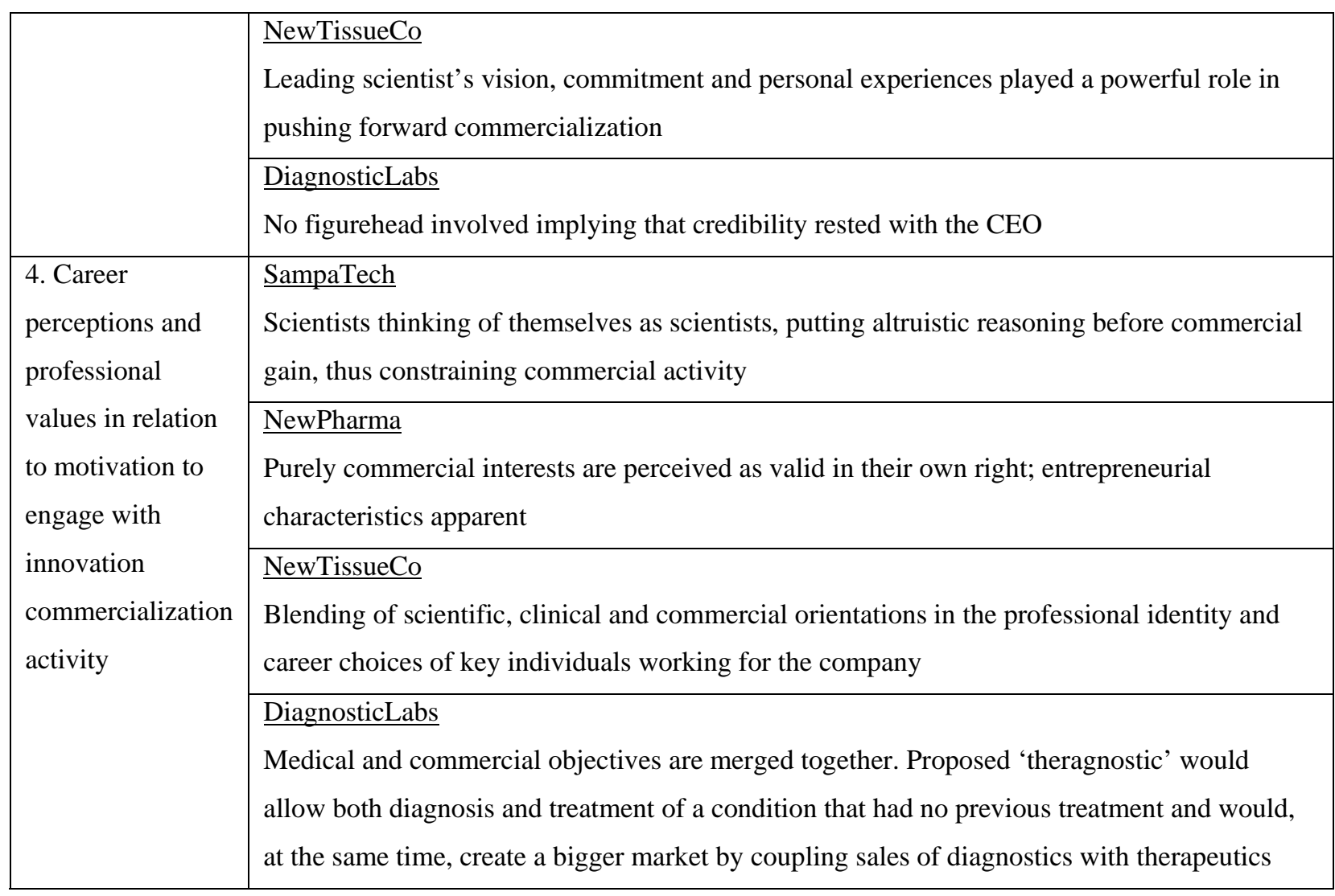


Table 2. Mechanisms Linked to Relational Capabilities

\begin{tabular}{|c|c|}
\hline Mechanisms & Examples From Cases \\
\hline \multirow[t]{4}{*}{$\begin{array}{l}\text { 5. Alignment of } \\
\text { interests and } \\
\text { expectations }\end{array}$} & $\begin{array}{l}\text { Body } \\
\text { Conducting two-way due diligence with potential partners to assess capabilities and resources but } \\
\text { also to negotiate interests and generate mutual understanding about expectations }\end{array}$ \\
\hline & $\begin{array}{l}\text { AmericanBio } \\
\text { In deciding which company to acquire, they looked for a 'cultural' match, which was decisive in } \\
\text { choosing between the two candidates. Thorough due diligence, however, was not sufficient to know } \\
\text { beforehand if clinical data was good enough }\end{array}$ \\
\hline & $\begin{array}{l}\text { NewTissueCo } \\
\text { Sought a licensing deal and investment from companies whose products, knowledge base, } \\
\text { experiences and capabilities related closely to, but at the same time complemented, their own }\end{array}$ \\
\hline & $\begin{array}{l}\text { DiagnosticLabs } \\
\text { One way due diligence did not explore alignment of interests. As a result, therapeutics company was } \\
\text { not interested in further investments in improving their IP. Further misalignment of interests } \\
\text { occurred with the decision of the owner to sell the company }\end{array}$ \\
\hline \multirow{4}{*}{$\begin{array}{l}\text { 6. Building } \\
\text { upon existing } \\
\text { networks to } \\
\text { generate } \\
\text { resources and } \\
\text { sustain more } \\
\text { risky and long } \\
\text { term projects }\end{array}$} & $\begin{array}{l}\text { Body } \\
\text { Company has a large number of diverse collaborations ranging through R\&D alliances to IP } \\
\text { licensing, that they drew upon to identify potential partners to take the product through to } \\
\text { development }\end{array}$ \\
\hline & $\begin{array}{l}\text { AmericanBio } \\
\text { Use clinicians from their existing network to promote the product by publishing results and } \\
\text { increasing the body of experience and patients }\end{array}$ \\
\hline & $\begin{array}{l}\text { NewTissueCo } \\
\text { Using one business deal to leverage others becomes an important way of enhancing commercial } \\
\text { credibility and so building the company securing resources for long term 'core' project }\end{array}$ \\
\hline & $\begin{array}{l}\text { DiagnosticLabs } \\
\text { Diagnostics company got involved in the project through personal networking of its CEO. Based on } \\
\text { the same relationship, free due diligence was conducted on the therapeutics IP }\end{array}$ \\
\hline \multirow{2}{*}{$\begin{array}{l}\text { 7. Using } \\
\text { networks to } \\
\text { shape } \\
\text { regulations and } \\
\text { ensure approval }\end{array}$} & $\begin{array}{l}\text { Body } \\
\text { Regulation expertise was considered important in selection of the potential partner, as Body would } \\
\text { rely on it to ensure approval }\end{array}$ \\
\hline & $\begin{array}{l}\text { AmericanBio } \\
\text { Company has a regulatory group dedicated to interaction with FDA. They were able to shape the } \\
\text { regulatory framework for the first generation product. Next generation product approval is also } \\
\text { being developed through interaction with FDA }\end{array}$ \\
\hline
\end{tabular}




\begin{tabular}{|l|l|}
\hline \multirow{5}{*}{$\begin{array}{l}\text { 'magnets' } \\
\text { 8. Product }\end{array}$} & $\begin{array}{l}\text { NewTissueCo } \\
\text { Founding scientists play an important role as opinion leaders and advocates for the (emerging) } \\
\text { discipline in scientific, business, political and public policy arenas }\end{array}$ \\
\cline { 2 - 3 } & $\begin{array}{l}\text { DiagnosticLabs } \\
\text { Using its connection to Bioclinical to access regulatory expertise }\end{array}$ \\
\hline & $\begin{array}{l}\text { Body } \\
\text { commerciapeutic in development is for a well recognized indication meaning relatively known path to }\end{array}$ \\
\cline { 2 - 3 } & $\begin{array}{l}\text { AmericanBio } \\
\text { ELBOW was the first product of its kind on the market }\end{array}$ \\
\cline { 2 - 3 } & $\begin{array}{l}\text { NewTissueCo } \\
\text { 'Revolutionary' nature of the work they are doing provides a focus for research, but also hampers } \\
\text { commercialization efforts }\end{array}$ \\
\cline { 2 - 3 } & $\begin{array}{l}\text { DiagnosticLabs } \\
\text { The 'theragnostic' concept was new and developed over time }\end{array}$ \\
\hline
\end{tabular}

